\title{
Prospects for growth hormone turn sour
}

Washington. Recombinant bovine growth hormone (rbGH), the drug that promised to be a boon to dairy farmers by increasing milk yields by as much as 5-25 per cent, suffered yet another setback last week when the US Congress, as part of President Bill Clinton's larger deficit-reduction bill, voted to enact a temporary ban on the sale of the hormone, pending the outcome of a study designed to assess the economic and social impact of this new drug on the US dairy industry.

The provision was adopted largely at the insistence of newly elected Senator Russell D. Feingold (Democrat, Wisconsin), who claims that if rbGH (also known as bovine somatotropin) is approved, the nation's milk surplus will increase, milk prices will drop and many small dairy farmers within his constituency will be driven out of business. A similar ban on rbGH currently exists in Europe and is likely to be extended for a further seven years when it expires at the end of this year (see Nature 364, 275; 1993).

The 90-day moratorium was just one of many last-minute compromises hatched between the administration and Congress in an effort by Clinton to round up the extra votes needed to pass his budget plan, which sets out to reduce the federal deficit by US $\$ 496$ billion over the next five years. In the end, Congress voted along party lines and the plan passed by a razor-thin margin of one vote in the Senate and two in the House of Representatives. Although many felt that a budget debate was no place for a discussion on a genetically engineered hormone for cows, Feingold's provision was considered fair game because of a congressional budget office projection that suggests use of rbGH could cost the government about US\$15 million a year in the purchase of surplus milk and dairy products for which farmers could find no other market.

Language that would have made the study a statutory requirement was dropped from the provision. However, Feingold says the administration has assured him that the Department of Agriculture either alone, or in conjunction with the Office of Management of Budget, will complete the study within 45 days of the moratorium taking effect.

Feingold, who first became involved with the issue as a Wisconsin state senator, has steered clear of the human health concerns surrounding the use of rbGH and focused solely on the economic and social issues. He had pushed for a one-year ban but says that he is satisfied with the compromise reached during the budget reconciliation process. This way, the ban will not take effect until after approval by the US Food and Drug Administration (FDA), and so a situation where the moratorium expires before FDA acts will not arise. And, although Feingold insists that his vote for Clinton's economic plan did not hinge on the ban being included, he admits saying to Clinton (who could ill afford to lose democratic votes in the Senate), "Look I'm supporting this package, I would very much like to have this one provision... stay there."

Some feared that the move could set a precedent for congressional interference in the review process for genetically engineered products. Representative Calvin M. Dooley (Democrat, California and co-chair of the Congressional Biotechnology Caucus), one of 41 House Democrats who voted against Clinton's economic plan last week, called it a "terrible policy for Congress to arbitrarily prohibit a product from being offered in the marketplace". It is an attempt by some members of Congress "to try to artificially maintain the status quo", he says. Although he admits that most dairy farmers have a lukewarm interest in using $\mathrm{rbGH}$, he nevertheless feels that it should be farmers, processors and consumers, and not Congress, who should decide the fate of rbGH after FDA has approved the drug.

Although Feingold claims that dairy farmers from states in the northeast and upper midwest will be disproportionately affected by the introduction of rbGH, Cooley says that what this boils down to is that these farmers are loosing their ability to maintain their competitiveness with farms in other regions of the country, such as California, the southwest and Texas.

The direct effects of the 90-day ban are likely to be slight, but Dooley worries about the kind of message this will send to investors in this fledgling industry. Besides having to decide whether companies have a viable product, investors will also have to be concerned about "the vagaries of Congress to impose restrictions that are not based on science". In this case, that meant "what I consider it would take to get another vote for a budget bill", he says.

As far back as 1985, FDA had said that milk and meat from cows treated with rbGH were safe for human consumption. Since then, despite favourable reviews by several other scientific committees and regulatory agencies, rbGH has remained mired in controversy and still awaits approval by FDA. Four companies - American Cyanamid, Elanco (a division of Eli Lilly), Monsanto and Upjohn - are seeking FDA approval for $\mathrm{rbGH}$.

Diane Gershon

\section{US doctors campaign to support rbGH}

San Francisco. The American Medical Association (AMA), keen to counter public resistance to biotechnology products, is backing a campaign to promote acceptance of the controversial recombinant bovine growth hormone ( $\mathrm{rbGH})$, likely to be one of the first products of agricultural biotechnology to reach the open market. The AMA has been given a grant of about $\$ 30,000$ from Monsanto Corporation to make a videotape endorsing the hormone for a weekend consumer programme on American Medical Television. The tape has already been distributed within the industry for educational purposes, but will not be shown on television until the treatment receives approval from US regulators.

The drug can, when injected into cows, boost milk production by 5 per cent to 25 per cent. The Food and Drug Administration has declared that its residue in milk is safe for human consumption and is expected soon to approve the treatment for use in dairies. But the discovery that some cows on the hormone are more susceptible to udder infections has raised concerns among consumers about the consequences for people's health of increased antibiotics in milk. In addition, many dairy farmers worry they will be forced by competition to use the product even though they believe it may create a glut and push smaller producers out of business.

Last month, the European Commission recommended a seven-year ban on the hormone, even though it had been given a clean bill of health by veterinary groups. Concerned at a similar reaction in the United States, the AMA's television programme argues that the drug could ease world hunger, and hints that consumer refusal to accept milk from treated cows could harm American competitiveness. The Pure Food Campaign, a public interest group opposed to biotechnology products, intends to launch a boycott against major dairy and grocery companies that sell milk from treated cows and to file lawsuits regarding human and animal safety, environmental safety and labelling.

M. Roy Schwarz, a senior vice president of the AMA, says the organization feels it should speak out in defence of a new generation of medicine. Schwarz said the AMA was concerned that opposition to $\mathrm{rbGH}$ in the United States reflected a broader reaction against products perceived as "different from nature." "You could have used similar arguments against penicillin," Schwarz said. "This fear must be confronted."

Monsanto, which is based in St Louis, Missouri, and is one of four manufacturers of the drug, has also contributed financial support to an educational hotline run by the American Dietetic Association to provide a positive message about the use of rbGH and its safety in milk.

Sally Lehrman 